Int. J. Plant Sci. 164(6):1007-1020. 2003.

(C) 2003 by The University of Chicago. All rights reserved.

$1058-5893 / 2003 / 16406-0016 \$ 15.00$

\title{
GYMNOSPERMS FROM THE MIDDLE TRIASSIC OF ANTARCTICA: THE FIRST STRUCTURALLY PRESERVED CYCAD POLLEN CONE
}

\author{
Sharon D. Klavins,* Edith L. Taylor,* Michael Krings, † and Thomas N. Taylor* \\ *Department of Ecology and Evolutionary Biology and Natural History Museum and Biodiversity Research Center, University of Kansas, \\ Lawrence, Kansas 66045-7534, U.S.A.; and +Bayerische Staatssammlung für Paläontologie und Geologie, Funktionseinheit \\ Paläontologie, Richard-Wagner-Strasse 10, 80333 Munich, Germany
}

\begin{abstract}
The first permineralized cycad pollen cone is described from the lower Middle Triassic of Antarctica. The cone is characterized by helically arranged, wedge-shaped microsporophylls, each with five or more spinelike projections extending from the rhomboid distal face. The vascular cylinder is dissected and produces paired traces to each microsporophyll. Three vascular bundles enter the base of the microsporophyll and divide to produce at least five vascular strands in the sporophyll lamina. Pollen sacs occur in two radial clusters near the lateral margins on the abaxial surface of the microsporophyll. Each cluster bears up to eight elongate pollen sacs that are fused for approximately half their length and display longitudinal dehiscence. Pollen sacs are sessile and attached to a vascularized, receptacle-like pad of tissue that is raised from the surface of the microsporophyll. Pollen is ovoid, psilate, and monosulcate. Although the affinities of this cone with the Cycadales are obvious, the complement of characters in the fossil is unique and thus does not permit assignment to an extant family. Features of the cone are evaluated against reproductive aspects of living cycads.
\end{abstract}

Keywords: Cycadales, Delemaya, gymnosperms, microsporophylls, pollen cone.

\section{Introduction}

The Cycadales are a relict group that represent one of the most ancient lineages of seed plants, with a fossil record that extends $>250$ million years (Zhu and Du 1981). Cycads are thought to have originated in the Carboniferous and reached a zenith of diversity and distribution during the Mesozoic, yet their evolutionary history has remained relatively poorly understood (Norstog and Nicholls 1997; Jones 2002). In part, this results from the co-occurrence in the fossil record of foliage that is morphologically similar to that of cycads but represents other gymnosperm groups (e.g., pteridosperms and Bennettitales), which may be only distantly related. In addition, reproductive structures of fossil cycads, which could yield significant data to help clarify the relationships of early cycads with other groups of seed plants, are rare. There are descriptions of cycad megasporophylls and pollen cones from the Permian of China (Zhu and Du 1981; Wang 1986; Gao and Thomas 1989; Zhu et al. 1994); however, all fossil cones currently assigned to the Cycadales are compressions that display overall morphology but preserve few details of internal organization. This has hindered elucidation of the affinities of early members of this group. Their relationships relative to other fossil and modern seed plants continue to remain problematic, although modern cycads are recognized as monophyletic (Crane 1985; Nixon et al. 1994; Rothwell and Serbet 1994; Doyle 1996, 1998; Magallón and Sanderson 2002; Rydin et al. 2002). Because suitable fossil evidence of cycads has been scarce, many recent phylogenetic analyses have been based on molecular data, although there is growing recognition

Manuscript received April 2003; revised manuscript received July 2003. that this approach has not been particularly successful in resolving relationships among extant seed plants, particularly with respect to taxa with extensive evolutionary histories (Donoghue and Doyle 2000; Qiu et al. 2000; Sanderson and Doyle 2001; Magallón and Sanderson 2002; Rydin et al. 2002; Soltis et al. 2002; Thorne and Kishino 2002). It is clear that integrating information from the fossil record is essential for reconstructing the phylogeny of modern plants. Therefore, each fossil taxon that can unequivocally be assigned to the Cycadales provides a critical data point that can be used to fill gaps in our current understanding of the fossil record of this group.

Here, we provide the first description of an anatomically preserved cycad pollen cone from the early Mesozoic. This specimen is part of an early Middle Triassic flora from the Fremouw Peak locality in the central Transantarctic Mountains that contains a wealth of structurally preserved plants, including stems of the small-statured cycad Antarcticycas schopfii Smoot, Taylor et Delevoryas (Smoot et al. 1985). Anatomical and morphological features affiliate the cone with Cycadales; however, the complement of characters observed in the fossil is unlike any that exists in cycads today. These features are compared with pollen cones of both extinct and extant cycads, which offer a rare opportunity to consider possible systematic and biological implications of these reproductive organs in an early representative of this ancient group of seed plants.

\section{Material and Methods}

The pollen cone is preserved in permineralized peat collected from Fremouw Peak in the Queen Alexandra Range of the 
central Transantarctic Mountains (84 ${ }^{\circ} 17^{\prime} 41^{\prime \prime} \mathrm{S}, 164^{\circ} 21^{\prime} 48^{\prime \prime} \mathrm{E}$, $2385 \mathrm{~m}$ a.s.l.; Barrett and Elliot 1973). The age of the upper Fremouw Formation is early Middle Triassic, on the basis of palynostratigraphic analysis and vertebrate fossils (Farabee et al. 1990; Hammer et al. 1990). Polished surfaces were etched in $49 \%$ hydrofluoric acid, and specimens were studied by preparing cellulose acetate peels (Galtier and Phillips 1999). Peels were mounted on microscope slides, which are housed in the Paleobotany Division of the Natural History Museum and Biodiversity Research Center, University of Kansas, Lawrence, under accession numbers 21434-21600 and 26026-26058.

For SEM, elevated wax wells were built directly around microsporophylls of interest on the surface of the silicified peat slab $11424 \mathrm{~L}_{\text {top }}$, and in situ pollen grains were macerated using $49 \%$ hydrofluoric acid (Osborn and Taylor 1993). Macerated material was transferred into microcentrifuge tubes, rinsed in water and acetone, and then poured onto a microscope slide. Once the acetone evaporated, an SEM stub with sticky tape was lightly pressed over the slide to pick up the scattered material. Stubs were coated with palladium gold and viewed with a JEOL JSM-1600 at $6 \mathrm{kV}$.

\section{Systematic Paleobotany}

Order-Cycadales

$$
\text { Family-Incertae sedis }
$$

Genus-Delemaya Klavins, Taylor, Krings et
Taylor gen. nov.

Generic diagnosis. Pollen cone simple, glabrous, elliptical in longitudinal section; vascular cylinder dissected into separate segments; tracheids annular to alternate pitted; microsporophylls helically arranged, imbricate, wedge shaped in longitudinal section, pentagonal in cross section, upturned tip forming rhomboid face with multiple projections directed toward cone apex; pollen sacs abaxial, in radial clusters, partially fused; pollen sac wall multilayered, dehiscence longitudinal; pollen ellipsoidal, monosulcate, psilate.

Type. Delemaya spinulosa sp. nov.

$$
\begin{gathered}
\text { Delemaya spinulosa Klavins, Taylor, Krings et } \\
\text { Taylor sp. nov. }
\end{gathered}
$$$$
\text { (Fig. 1; Fig. 2A, 2C-2E; Fig. 3A-3F) }
$$

Specific diagnosis. Cone at least $30 \mathrm{~mm}$ long; microsporophylls with three vascular bundles at base, at least five distally; at least five sharp-tipped projections at microsporophyll face, central projection longest; microsporophylls with two distinct radial clusters of pollen sacs separated by a sterile keel; each cluster with up to eight sessile pollen sacs on elevated, vascularized receptacular pad; spherical cortical cavity lacking contents at point of attachment of pollen sacs; pollen sacs elongate, up to $1 \mathrm{~mm}$ long and $0.5 \mathrm{~mm}$ wide, fused for up to half their length; pollen sac wall of two to three layers of thinwalled cells beneath distinct, thick-walled epidermis; wall thickness increases toward apex of pollen sac; pollen up to 20 $\mu \mathrm{m}$ long and $15 \mu \mathrm{m}$ wide, sulcus smooth.

Derivation of name. The generic name Delemaya is pro- posed in honor of Ted Delevoryas and Sergius H. Mamay, both of whom have made highly significant contributions to our current understanding of the evolutionary history of cycads. The specific epithet spinulosa (Latin) refers to the small spines on the upturned distal tips of the microsporophylls.

Types. Holotype, 159 slides of specimen $11424 \mathrm{M}_{\text {bot }}$, slide numbers 21434-21438; 21440-21579; 26029-26048; fig. 1; fig. 2A, 2C-2E; fig. 3A-3E. Paratype, 35 slides of $11424 \mathrm{~L}_{\text {top }}$, slide numbers 21438 ; 21580-21600; 26026-26028; 2604926058; fig. $2 B$.

Repository. Division of Paleobotany, Natural History Museum and Biodiversity Research Center, University of Kansas, Lawrence.

Locality. Fremouw Peak, Queen Alexandra Range, Antarctica $\left(84^{\circ} 17^{\prime} 41^{\prime \prime} \mathrm{S}, 164^{\circ} 21^{\prime} 48^{\prime \prime} \mathrm{E}, 2385 \mathrm{~m}\right.$ a.s.l.), Buckley Island Quadrangle, Barrett and Elliott, 1973.

Stratigraphy. Upper portion of the Fremouw Formation. Age. Early part of the Middle Triassic.

\section{Description}

The description that follows is on the basis of a pollen cone that occurs in close proximity to a stem of Antarcticycas schopfii but not in organic attachment. The cone is well preserved at the apex; however, the quality of preservation decreases toward the proximal end. Features described here are therefore primarily based on those observed in more apical microsporophylls. The cone is simple, glabrous, elliptical in longitudinal section, and at least $30 \mathrm{~mm}$ long and $8 \mathrm{~mm}$ wide (fig. 1A). Because the cone is small, no attempt was made to reorient the specimen by selective grinding to obtain a more median longitudinal section. The base of the cone is incomplete and therefore the total length could not be determined. Microsporophylls are wedge shaped in longitudinal section, helically arranged, and bear pollen sacs on the abaxial surface (fig. 1A). The apex of each microsporophyll is upturned, forming a rhomboid face with at least five elongate, sharp-tipped projections that extend toward the cone apex (fig. 2B). Pollen sacs are clustered into two separate radial clusters on each microsporophyll (fig. 2A), with up to eight pollen sacs per cluster (fig. $3 B$ ). Pollen sacs dehisce by a longitudinal slit (fig. $3 C)$. Pollen is psilate, monosulcate, and ellipsoidal in outline (fig. 3F).

\section{Cone Axis}

The pith of the cone axis measures up to $1.1 \mathrm{~mm}$ in diameter and is composed of thick-walled, isodiametric cells that lack contents (fig. 1B). No secretory structures occur in the pith. A vascular cylinder that is dissected into multiple bundles surrounds the pith (fig. $1 B$ ). Each bundle consists of tracheids with annular to scalariform thickenings, or alternate pitting (fig. $1 B$ ). It is not possible to distinguish between protoxylem and metaxylem; secondary xylem is absent. Phloem cells are not preserved, although areas in which phloem probably occurred appear lighter in color. Traces to each microsporophyll are produced helically and originate as two bundles produced from the neighboring ends of two adjacent segments (sympodia) of the vascular cylinder in the cone axis. As the trace progresses through the cortex, one bundle dichotomizes so that 

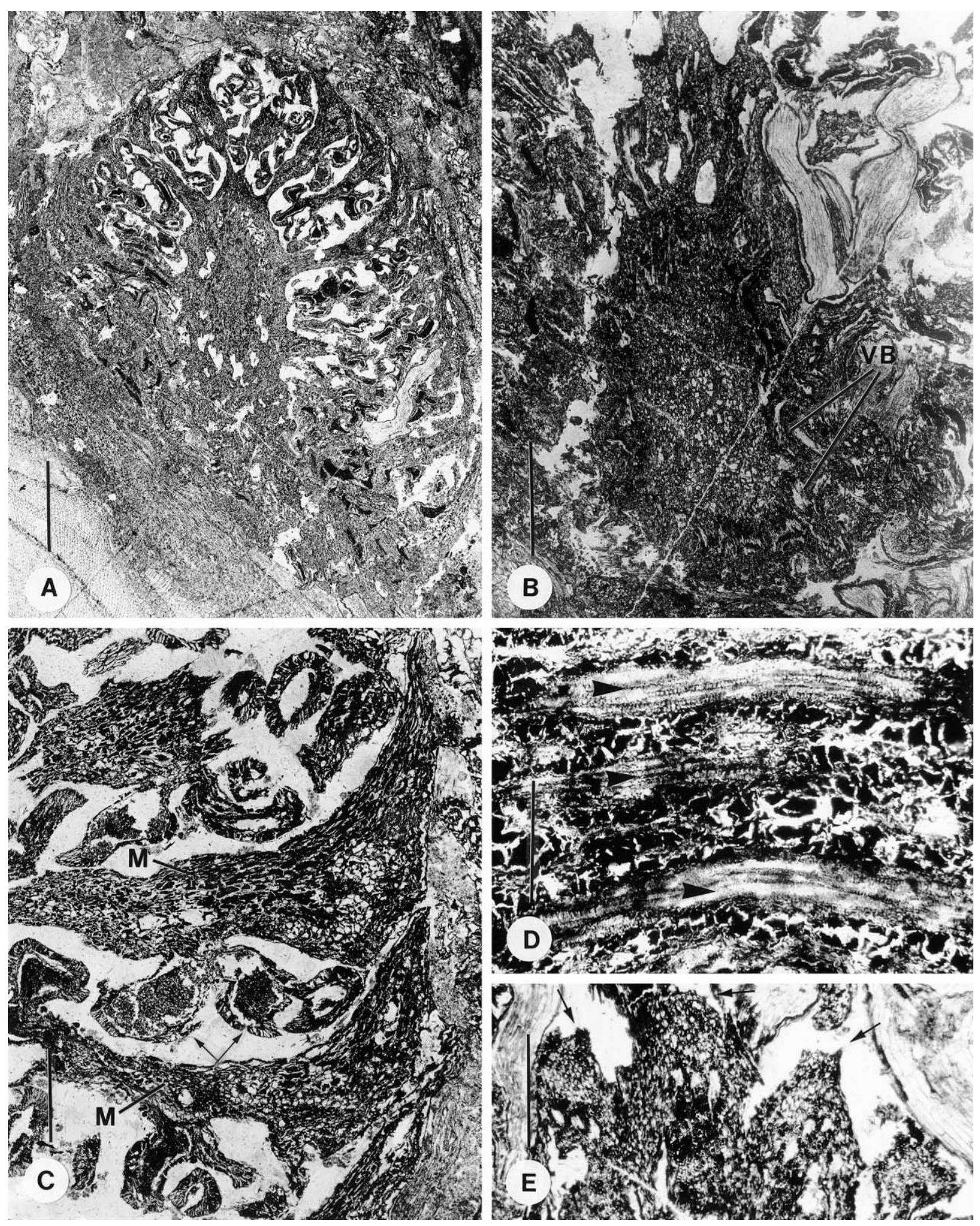

Fig. 1 Delemaya spinulosa gen. et sp. nov. A, Oblique longitudinal section through the apical region of the pollen cone. Note ring of cavities in the cortex of the cone axis. Scale bar $=2 \mathrm{~mm}$. Slide 21434; $10424 \mathrm{M}_{\mathrm{bot}}$, number 115 . B, Oblique cross section through the cone axis showing pith and dissected bundles $(V B)$ of the vascular cylinder. Scale bar $=1 \mathrm{~mm}$. Slide $21435 ; 10424 \mathrm{M}_{\mathrm{bot}}$, number 42 . C, Longitudinal section through two microsporophylls $(M)$ with clusters of pollen sacs (arrows) attached approximately midway along the microsporophylls. Note elongate, sharp-tipped projections at the distal face (right side). Scale bar $=500 \mu \mathrm{m}$. Slide 21434; $10424 \mathrm{M}_{\text {bor }}$, number 115 . $D$, Longitudinal section of a microsporophyll trace with three vascular bundles (arrowheads) comprised of scalariform tracheids. Scale bar $=10 \mu \mathrm{m}$. Slide 21436; $10424 \mathrm{M}_{\mathrm{bot}}$, number 92. E, Cross section through the bases of three microsporophylls (arrows) attached to the cone axis; each has three light areas corresponding to the position of vascular bundles. Scale bar $=500 \mu \mathrm{m}$. Slide $21437 ; 10424 \mathrm{M}_{\mathrm{bot}}$, number 18 . 

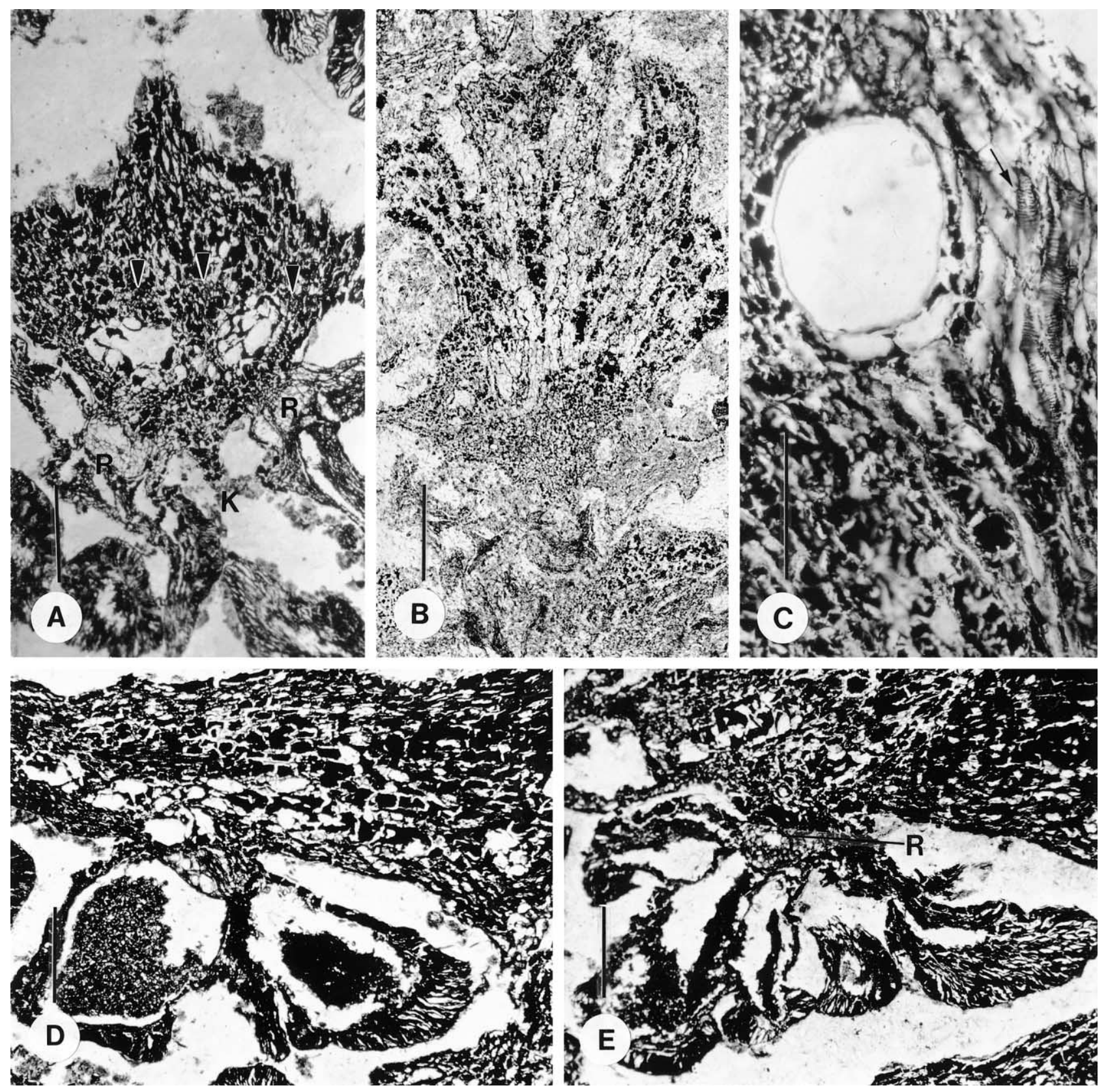

Fig. 2 Delemaya spinulosa gen. et sp. nov. A, Cross section through a microsporophyll with two clusters of pollen sacs on the abaxial surface separated by a sterile keel $(K)$. Sessile pollen sacs are attached to parenchymatous, elevated receptacles $(R)$; note also the ridges on the adaxial surface. Position of vascular bundles indicated by arrowheads. Scale bar $=250 \mu \mathrm{m}$. Slide $21438 ; 10424 \mathrm{M}_{\mathrm{bot}}$, number 39 . B, Paradermal section near the distal face of a microsporophyll, showing multiple adaxial projections. Scale bar $=500 \mu \mathrm{m}$. Slide $21439 ; 10424 \mathrm{~L}_{\text {top }}$, number 25 . C, Detail of cortical cavity and scalariform tracheids (arrow) in receptacle. Scale bar $=10 \mu \mathrm{m}$. Slide 21434; 10424 $\mathrm{M}_{\mathrm{bot}}$, number 115 . $D$, Longitudinal section through a microsporophyll, showing two sessile pollen sacs attached to a parenchymatous receptacle. Scale bar $=250 \mu \mathrm{m}$. Slide 21440 ; $10424 \mathrm{M}_{\mathrm{bot}}$, number 81. E, Longitudinal section through a microsporophyll, showing a cluster of five pollen sacs attached to the receptacle (R). Scale bar $=250 \mu \mathrm{m}$. Slide 21441; $10424 \mathrm{M}_{\mathrm{bot}}$, number 67.

three vascular bundles enter the base of each microsporophyll (fig. 1D). Cells with opaque contents surround the vascular bundles and extend into the microsporophylls. Cells of the cortex are thin walled and isodiametric, like those in the pith. There are numerous hollow cavities present throughout the tissue (fig. 1A).

\section{Microsporophylls}

Microsporophylls are arranged helically on the cone axis, with imbricated rhomboid faces (fig. 4A) and wedge shaped in longitudinal section, with a slight abaxial keel and upturned apex (fig. 1C). Each microsporophyll measures up to $5 \mathrm{~mm}$ 

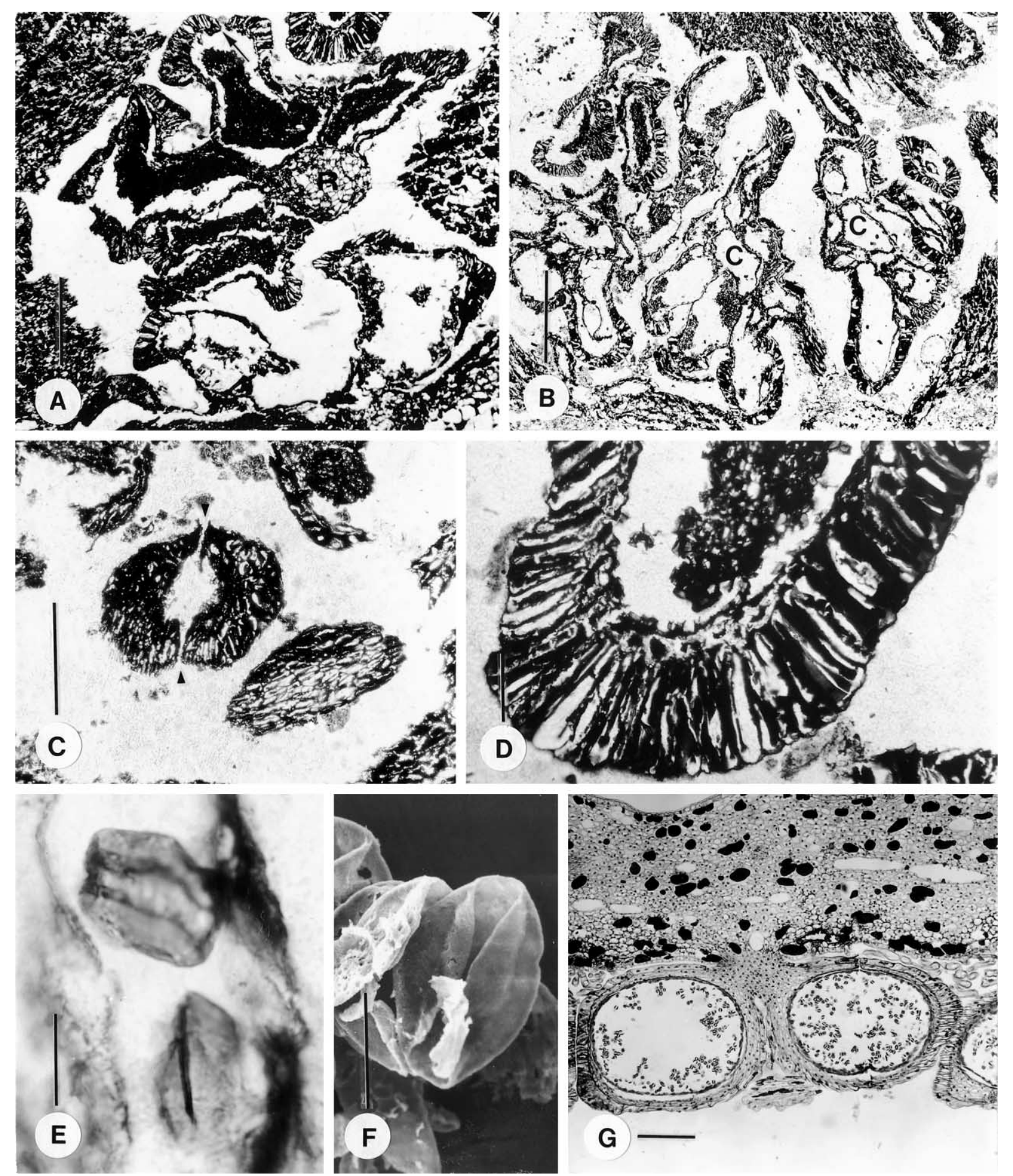

G

Fig. $3 A-F$, Delemaya spinulosa gen. et sp. nov. G, Zamia furfuracea. A, Cross section through a single cluster of pollen sacs attached radially around the parenchymatous receptacle $(R)$. Note dehiscence slit (arrow). Scale bar $=250 \mu \mathrm{m}$. Slide 21442; $10424 \mathrm{M}_{\mathrm{bot}}$, number 68 . B, Cross section through two radial clusters of pollen sacs that are attached to a single microsporophyll. Each cluster has five to six fused pollen sacs radially arranged around a central cavity $(C)$. Scale bar $=500 \mu \mathrm{m}$. Slide $21443 ; 10424 \mathrm{M}_{\text {bot }}$, number 128 . C, Paradermal section through two pollen sacs, on the left showing dehiscence zones on both sides of the pollen sac (arrowheads), and on the right showing elongate cells of the epidermis. Scale bar $=250 \mu \mathrm{m}$. Slide $21444 ; 10424 \mathrm{M}_{\mathrm{bot}}$, number 69 . D. Cross section through the wall of a pollen sac showing the multilayered structure with one to two layers of internal isodiametric cells and a single layer of rectangular epidermal cells. Scale bar $=5 \mu \mathrm{m}$. Slide 21444 ; $10424 \mathrm{M}_{\mathrm{bot}}$, number 69. E, In situ pollen grains. Scale bar $=10 \mu \mathrm{m}$. Slide 21444; $10424 \mathrm{M}_{\mathrm{bot}}$, number 69. F, SEM of pollen grains showing psilate surface and flared sulcus. Scale bar $=10 \mu \mathrm{m}$. G, Longitudinal section through a microsporophyll of Z. furfuracea with stalked, paired pollen sacs and cortical secretory cavity above point of attachment. Note also the multiseriate wall and increase in size of epidermal cells at the apex of the pollen sacs. Scale bar $=250 \mu \mathrm{m}$. NYBG V-91-01-H, 1-7. 

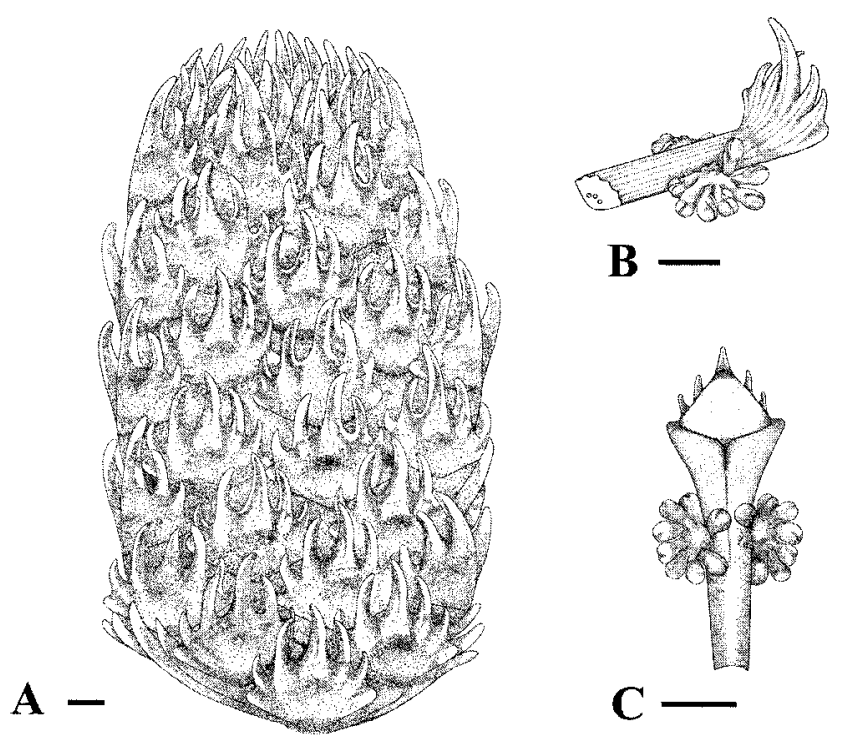

Fig. 4 Suggested reconstructions of Delemaya spinulosa. A, Cone morphology, showing helical arrangement of microsporophylls and organization of projections on microsporophyll faces. Scale bar $=1$ $\mathrm{mm}$. $B$, Morphology of a microsporophyll, showing the position of pollen sacs and extension of adaxial ridges into apical projections at the microsporophyll face. Scale bar $=2.5 \mathrm{~mm}$. C, Abaxial view of a microsporophyll, showing the organization of the pollen sacs into two radial clusters. Scale bar $=2.5 \mathrm{~mm}$.

long. Near the base, microsporophylls are rhomboidal to pentagonal in cross section, with a ridge on the adaxial (upper) surface, and measure $0.5 \mathrm{~mm}$ wide. Additional adaxial ridges appear in more distal regions of the sporophyll (fig. 2A) and extend to the upturned apex, where they expand into five sharp-tipped projections oriented toward the cone apex (fig. $2 B)$. The middle projection is the longest $(3.6 \mathrm{~mm}$ long at lower levels in the cone). The distal face of the microsporophylls is rhomboidal in overall shape and measures up to $4 \mathrm{~mm}$ wide. There is no evidence of trichomes or other epidermal outgrowths on any surface of the microsporophylls, nor have stomata been observed.

Three separate vascular bundles, composed of annular to scalariform tracheids (up to $24 \mu \mathrm{m}$ in diameter), occur in the base of each sporophyll (fig. $1 E$ ). The two clusters of pollen sacs are vascularized by single strands that become continuous with the lateral bundles. A large (up to $250 \mu \mathrm{m}$ ) spherical cavity occurs in the receptacle of each cluster (fig. 2C). These cavities are empty and do not appear to have an epithelial lining. Similar structures also occur in modern Zamia furfuracea Aiton (fig. 3G). Additional cavities appear throughout the microsporophyll lamina (figs. $1 \mathrm{C}, 2 \mathrm{~A}$ ), but it is not clear whether these are secretory. Two of the vascular bundles divide distal to the point of attachment of the pollen sacs. As a result, the distal regions of the microsporophyll contain five vascular bundles in a curvilinear arrangement (fig. $2 A$, arrows). Bundles extend into the sharp-tipped projections that project from the face of the microsporophyll.

\section{Pollen Sacs and Pollen}

Microsporophylls bear from eight to 16 pollen sacs, which occur in two separate clusters positioned near the lateral margins on the abaxial surface of the sporophyll, approximately midway between the sporophyll face and the point of attachment to the cone axis (figs. 1C, 2A). Clusters of pollen sacs at the apex of the cone bear fewer pollen sacs than those below. A sterile region that forms a keel at the tip of the sporophyll separates the fertile regions (fig. $2 A$ ). Each cluster has up to eight pollen sacs organized radially; some are oriented with their distal tips toward the cone apex. Pollen sacs are sessile and broadly attached to a central parenchymatous receptacle that is slightly elevated from the abaxial surface of the microsporophyll (fig. $2 A, 2 D, 2 E$; fig. $3 A$ ). The receptacle is vascularized by tracheids with scalariform thickenings that extend throughout the parenchymatous pad (fig. 2C, arrow). Within a single cluster, pollen sacs are entirely fused to one another for up to half of their length, with their distal tips free (figs. $2 E, 3 B)$. Pollen sacs are elongate and measure up to $1 \mathrm{~mm}$ long and $0.5 \mathrm{~mm}$ wide. Dehiscence occurs by a single longitudinal slit that extends around the apex of the pollen sac (fig. $3 A, 3 C)$; as a result, pollen sacs open by two nearly equal valves (fig. $3 C$ ).

The pollen sac wall is multilayered, with two or three layers of small-diameter, thin-walled cells present beneath a distinct epidermis (fig. 3D). We are unable to determine whether the pollen sac walls are cutinized. The wall varies in thickness, reaching the greatest dimensions at the apex, where it measures up to $130 \mu \mathrm{m}$ thick (fig. $3 B$ ). Epidermal cells are narrow, rectangular to nearly triangular in longitudinal section, and thick walled (fig. 3D). In paradermal view, these cells are elongate (fig. $3 C$ ). Where pollen sacs are fused, the wall is thin and individual cells indistinct (fig. $2 E$; fig. $3 A, 3 B$ ). All pollen sacs in the cone appear to be at approximately the same level of development and contain mature pollen grains. Many sacs display a narrow opening on one or both sides and appear to have dehisced, although pollen frequently remains present. Pollen grains may be free but are more often aggregated into a compact mass, perhaps held together by remnants of a tapetal membrane (figs. $1 C, 2 D, 3 A$ ). This does not appear to be correlated with position in the cone and may instead be the result of taphonomic or diagenetic processes.

Pollen is ellipsoidal in outline, longitudinally monosulcate, and bilaterally symmetrical (fig. $3 E, 3 F$ ). It appears to be similar to the dispersed pollen taxon Cycadopites Wodehouse ex L. R. Wilson et R. M. Webster. Individual grains range up to $15 \mu \mathrm{m}$ wide and ca. $20 \mu \mathrm{m}$ long. The sulcus occupies the length of the grain and is slitlike at the center, flaring up to $4 \mu \mathrm{m}$ wide at the ends (fig. 3F). The surface is psilate, although numerous pits are visible in the surface of the grains. These are interpreted as the result of postdepositional degradation of the wall. Preliminary examination of ultrastructural thin sections suggests that the wall is homogeneous, with little indication of the alveolate structure found in modern cycad pollen grains. We are uncertain about whether the ultrastructure of the Delemaya pollen wall is, in fact, naturally homogeneous or is the result of extensive compression and the various diagenetic processes involved in preservation. We are currently 
examining fine structural details of these grains; this information will be presented in a subsequent article.

\section{Discussion}

Among extant seed plants, conifers, taxads, and cycads can have microsporophylls organized into simple cones, and the overall structural organization of these cones may be similar (Bierhorst 1971). Cones in most of these groups have helically arranged microsporophylls and abaxial pollen sacs; however, whereas noncycad taxa typically bear $\leq 15$ pollen sacs per microsporophyll, some species of cycads (e.g., Cycas media R. Brown) can bear $>1000$ (Chamberlain 1935; Bierhorst 1971). Conifer fossils assignable to the Podocarpaceae (Notophytum krauselii Meyer-Berthaud et Taylor) and Taxodiaceae (Parasciatopitys aequata Yao, Taylor et Taylor) have been discovered in the flora from Fremouw Peak (Meyer-Berthaud and Taylor 1991; Yao et al. 1997; Axsmith et al. 1998), which might indicate that this cone represents the pollen-producing structure of one of these taxa. Pollen cones of modern Podocarpaceae are characterized by having two pollen sacs per microsporophyll and bisaccate pollen (Bierhorst 1971), which differs significantly from Delemaya. In extant Taxodiaceae, pollen cones can bear up to 10 pollen sacs per microsporophyll and have inaperturate or monocolpate pollen (Aulenback and LePage 1998); however, pollen sacs are not organized in radial clusters. Comparisons with other Triassic conifers such as Voltziostrobus Grauvogel-Stamm and Sertostrobus GrauvogelStamm also reveal significant differences in that both Voltziostrobus and Sertostrobus bear pollen sacs on elongate pedicels on the adaxial surface of the microsporophyll (GrauvogelStamm 1969). Overall, the complement of characters in this fossil cone is distinctly cycadalean. The primary features that support this assignment are organization of pollen sacs into radial clusters (sometimes referred to as "sori") on microsporophylls; multiseriate organization of the pollen sac wall, with a thick-walled epidermal layer; and the presence of monosulcate, ellipsoidal pollen. Although there is a report of an anatomically preserved cycad pollen cone from the Carboniferous (Taylor 1968), subsequent studies have concluded that its affinities are uncertain (Taylor 1970; Taylor and Millay 1977). Thus, Delemaya spinulosa is the first fossil pollen cone that can unequivocally be assigned to the cycads on the basis of anatomical features.

Delemaya spinulosa occurs in close proximity to a stem of Antarcticycas schopfii, which is currently the only cycad known to occur in the permineralized peat found at Fremouw Peak (Taylor et al. 2000). This strengthens the possibility that it is the pollen cone of A. schopfii. There are, however, no histological features that provide further evidence for connection, nor are patterns of structural similarity in cone and stem anatomy well known even in modern cycads. In addition, all other cycad pollen cone taxa known to date are based on compression fossils, which bear a completely different complement of features and provide little basis for comparison. For these reasons, we have chosen to assign this cone to a new genus and species.

Although compressions of fossil cones attributed to the Cycadales have been known for $>100 \mathrm{yr}$, their organization has been understood only in terms of general morphology and pollen structure (Hill 1990 and references therein). The gross morphological features of $D$. spinulosa (fig. 4A) support the prevailing view that early cycad pollen cones possessed an organization similar to that of modern cycads (Thomas and Harris 1960; Delevoryas and Hope 1971; Hill 1990; Krassilov et al. 1996); however, some of the structural characters in this cone are not otherwise known in the Cycadales. As such, it provides a critical suite of features that may be of systematic significance; these include patterns of microsporophyll vasculature, organization and arrangement of the pollen sacs, and microsporophyll morphology.

The cone axis vasculature consists of a eustele that is dissected into numerous individual bundles, the result of the production of a large number of helically arranged microsporophyll traces, which also occurs in pollen cones of both extant cycads and conifers (Scott 1897). In the fossil cone, two adjacent cauline bundles produce two trace bundles, a pattern also observed in Zamia loddigesii Miq.; however, only a single bundle is produced in the trace of Bowenia spectabilis Hook. (Worsdell 1898), and patterns of trace emission remain poorly known in other cycad taxa. In conifers as well, the range of variation in the pattern of trace emission to microsporophylls is not well known but typically appears to be a single bundle. In Delemaya, one of the two initial bundles of the microsporophyll trace divides so that three bundles enter the base of each microsporophyll; two of these subsequently bifurcate to produce at least five strands that extend into the distal projections. In modern cycads, the number of bundles entering the microsporophyll varies (Worsdell 1898) but does not appear to be correlated with total number of pollen sacs. Some species of Cycas L. bear $>1000$ pollen sacs with only a single vascular bundle documented as entering the base of microsporophylls (Thibout 1896), whereas Zamia L. typically bears $<50$ pollen sacs, and each sporophyll has three to six vascular bundles at the base (Worsdell 1898; Chamberlain 1935). It is not yet clear whether these features are taxonomically significant, and further investigation is needed.

The pattern of organization of vascular bundles in the microsporophyll appears to be consistent within genera and has been correlated with overall sporophyll morphology (Worsdell 1898; Stevenson 1990). Microsporophylls with a flattened lamina (e.g., Cycas, Stangeria T. Moore) display a linear arrangement of vascular bundles, while those with an expanded, peltate apex (e.g., Zamia L.) have a more complex, nonlinear, and three-dimensional arrangement in distal regions (cf. fig. 52 with fig. 55 in Stevenson 1990). Although the position of vascular bundles is often obscure in microsporophyll cross sections of D. spinulosa (e.g., fig. 2A), their almost linear arrangement supports the interpretation of the microsporophylls as flattened rather than peltate. These anatomical features demonstrate the overall similarity of the fossil cone to those of extant taxa; however, significant differences become more apparent in the arrangement and organization of pollen sacs on the microsporophyll. There is little information available to date on organization of pollen sacs in fossil cycads. Although the full range of variation in pollen cones of extant cycads has not been completely investigated in detail, differences nonetheless have been documented that are informative at the generic or familial level. Some of these include the number of pollen sacs per microsporophyll, number of pollen sacs in each 
radial cluster, and degree of fusion of the pollen sac stalks (Stevenson 1990; Norstog and Nicholls 1997; Jones 2002; Whitelock 2002). These characters, generally not adequately preserved in compression fossils of cycad cones, are revealed in exquisite detail in the specimen from Fremouw Peak.

Delemaya spinulosa differs from its extant relatives with respect to the organization of pollen sacs, both in number of sacs per radial cluster and per microsporophyll and in the attachment and fusion of the pollen sacs. The fossil cone appears to bear up to eight pollen sacs in a single cluster (fig. $4 B, 4 C)$ and probably bore $<20$ pollen sacs per microsporophyll. In contrast, most modern cycads typically bear radial clusters comprised of no more than five pollen sacs and may have several hundred pollen sacs per microsporophyll; only Chigua D. W. Stevenson, Zamia, and Bowenia W. J. Hooker ex J. D. Hooker have $\leq 50$ (table 1). Coulter and Chamberlain (1917) hypothesize that a large number of pollen is an ancestral character in cycads, whereas small numbers are derived. Both Semionandra laxa Krassilov et Bugdaeva, a putative cycad from the Lower Cretaceous of Russia (Krassilov and Bugdaeva 1988), and D. spinulosa possess a small number of pollen sacs, which indicates that this character has been present in the Cycadales since at least the early Mesozoic. Thus, Coulter and Chamberlain's hypothesis may not be entirely supported by evidence from the fossil record to date. Alternatively, a reduced number of pollen sacs per microsporophyll either may have evolved before the early Mesozoic or has had multiple origins in the Cycadales.

The pollen sacs of $D$. spinulosa structurally resemble those of modern cycads, particularly in sporangial wall organization. Walls of the pollen sacs are multilayered at maturity, a feature that distinguishes cycads from conifers and taxads (Coulter and Chamberlain 1917; Gifford and Foster 1989). Epidermal cells are narrow and elongate, with thickened walls, and increase in size at the apex of the pollen sac; this also occurs in extant cycads (cf. fig. $2 D$ with fig. $3 G$ ). On the other hand, whereas pollen sacs of extant cycads have stalks and attach directly to the microsporophyll, pollen sacs in D. spinulosa are sessile and attach to a vascularized, receptacular pad of tissue on the abaxial surface of the microsporophyll. Moreover, the pollen sacs in an individual cluster are fused to one another for at least half of their length and thus may be interpreted as synangiate. Although Chamberlain (1935) states explicitly that pollen sacs in modern cycads are not synangiate, most taxa are now interpreted as showing some degree of fusion of pollen sac stalks (Bierhorst 1971; Stevenson 1990; Jones 2002). In addition, plurilocular structures have been reported in Cycas and Zamiaceae (particularly Macrozamia Miquel) (Bierhorst 1971; Stevenson 1990). Partly fused pollen sacs have also been described in the suggested cycads Cycandra profusa Krassilov, Delle et Vladimirova from the Upper Jurassic and S. laxa (Krassilov and Bugdaeva 1988; Krassilov et al. 1996). Synangial pollen organs are a characteristic feature of late Paleozoic pteridosperms, which have been suggested as cycad progenitors for more than a century (Worsdell 1896, 1906; Scott 1909). It is interesting to note that the broad attachment of the pollen sacs in each cluster to a raised, vascularized receptacle in $D$. spinulosa is also present in some Paleozoic pteridosperms (e.g., Feraxotheca culcitaus Millay et Taylor (Lyginopteridales) and Idanothekion callistophytoides (Stidd et Hall) Rothwell (Cal- listophytales) (Stidd and Hall 1970; Millay and Taylor 1977, 1979; Rothwell 1980).

The pollen of $D$. spinulosa (fig. $3 E, 3 F$ ) closely resembles pollen of modern cycads, which is characterized as ellipsoidal, longitudinally monosulcate, and bilaterally symmetrical (Audran and Masure 1977; Dehgan and Dehgan 1988; Marshall et al. 1989). Pollen in D. spinulosa is comparable in size (average $=20 \mu \mathrm{m}$ ), although on the low end of the range for extant cycads (19-49 $\mu \mathrm{m})$ (Dehgan and Dehgan 1988). In addition, psilate surface texture is not uncommon in cycads $(\mathrm{Au}-$ dran and Masure 1977; Dehgan and Dehgan 1988; Marshal et al. 1989). Although monosulcate pollen is characteristic of cycads, similar pollen morphology can be found in extant and fossil Ginkgo; however, organization of the Ginkgo pollen cone differs significantly from that of Delemaya. Although the pollen sac organization of $D$. spinulosa differs somewhat from that of modern cycad pollen cones, pollen morphology strongly affiliates it with the Cycadales.

\section{Cone Morphology}

The anatomical features present in D. spinulosa also provide an increased understanding of overall cone morphology. The cone appears to be ellipsoidal in outline, with the tips of the microsporophylls imbricate (fig. 4A). In comparison with most modern taxa, the cone is relatively small. This may be related to the suggested slender stature of its possible parent plant, $A$. schopfii (Smoot et al. 1985). The size of the fossil cone is, however, comparable to several species of Androstrobus Schimper (Thomas and Harris 1961) and pollen cones of some extant taxa (e.g., Zamia pygmaea Sims; Whitelock 2002). The small size of the cone could also be interpreted as representing an early stage of development. In modern cycads, microsporophylls remain tightly appressed until maturity, when the cone axis elongates by increase in cell length, which results in separation of the microsporophylls and exposure of the pollen sacs. With additional space between microsporophylls, pollen sacs continue to mature and may show evidence of ontogenetic distortion that reflects crowding during development (Bierhorst 1971). In this specimen, however, the cone axis appears to have initiated elongation because the apical microsporophylls show slight separation, pollen sacs are mature and some are dehisced, and pollen grains are free (figs. $1 A, 2 D, 3 E$ ). The varied orientation of the pollen sacs (fig. $1 A$ ) indicates ontogenetic distortion and/or crowding the pollen sacs, similar to that in modern cycads. This combination of features indicates that the cone was preserved at or close to maturity and thus that it was compact relative to modern cycad cones. Because we remain uncertain about the overall length of the cone, it is possible that our interpretation of few pollen sacs per microsporophyll simply reflects better preservation of the apical region of the fossil cone. Chamberlain (1935) notes that microsporophylls near the apex of many cones bear a reduced number of pollen sacs, with some taxa displaying completely sterile apical microsporophylls. In D. spinulosa, however, the apical microsporophylls are fertile. In addition, proximal microsporophylls also appear to bear only two clusters of pollen sacs. This tends to support the hypothesis that a low number of pollen sacs per microsporophyll was the norm in $D$. spinulosa. 
Table 1

Comparison of Features of Delemaya spinulosa and Modern Cycad Pollen Cones

\begin{tabular}{|c|c|c|c|c|c|c|c|c|c|c|c|c|}
\hline & \multirow[b]{3}{*}{ Delemaya } & \multirow{3}{*}{$\begin{array}{c}\text { Cycadaceae } \\
\text { Cycas }\end{array}$} & \multicolumn{2}{|c|}{ Stangeriaceae } & \multicolumn{8}{|c|}{ Zamiaceae } \\
\hline & & & \multirow[b]{2}{*}{ Stangeria } & \multirow[b]{2}{*}{ Bowenia } & \multicolumn{3}{|c|}{ Zamieae } & \multirow{2}{*}{$\frac{\text { Ceratozamieae }}{\text { Ceratozamia }}$} & \multicolumn{3}{|c|}{ Encephalarteae } & \multirow{2}{*}{$\frac{\text { Diooeae }}{\text { Dioon }}$} \\
\hline & & & & & Zamia & Chigua & Microcycas & & Encephalartos & Macrozamia & Lepidozamia & \\
\hline $\begin{array}{l}\text { Microsporophyll } \\
\text { face shape } \\
\text { Microsporophyll }\end{array}$ & Rhomboid & Rhomboid & Rhomboid & Hexagon & Hexagon & Hexagon & Hexagon & Hexagon & Rhomboid & Rhomboid & Rhomboid & Rhomboid \\
\hline $\begin{array}{l}\text { arrangement } \\
\text { Distal face }\end{array}$ & Imbricate & Imbricate & Imbricate & Vertical rows & Vertical rows & Vertical rows & Vertical rows & Vertical rows & Imbricate & Imbricate & Imbricate & Imbricate \\
\hline projections & $\begin{array}{l}\text { At least five } \\
\text { sharp spines, } \\
\text { central spine } \\
\text { longest }\end{array}$ & $\begin{array}{l} \pm \text { single sharp spine } \\
\text { projecting apically, } \\
\text { some with one to } \\
\text { six minute teeth } \\
\text { to either side }\end{array}$ & Flat & $\begin{array}{c}\text { Central de- } \\
\text { pression }\end{array}$ & $\begin{array}{l}\text { Flat to fac- } \\
\text { eted }\end{array}$ & $\begin{array}{l}\text { Flat to fac- } \\
\text { eted }\end{array}$ & $\begin{array}{l}\text { Faceted with } \\
\text { central facet } \\
\text { projecting to } \\
\text { a blunt tip }\end{array}$ & Two spines & $\begin{array}{l}\text { Faceted with } \\
\text { central facet } \\
\text { often project- } \\
\text { ing to a blunt } \\
\text { tip }^{\mathrm{b}}\end{array}$ & $\begin{array}{l}\text { Terminal sharp } \\
\text { spine }\end{array}$ & $\begin{array}{l}\text { Apex inflated, tip } \\
\text { extends in a } \\
\text { single spine }\end{array}$ & $\begin{array}{l}\text { Top of face pro- } \\
\text { jects slightly }\end{array}$ \\
\hline $\begin{array}{l}\text { Pollen sacs/micro- } \\
\text { sporophyll }\end{array}$ & $<20$ & $>700$ & $>150$ & $>50$ & $<25$ & ? & $>200$ & $>150$ & $500-700$ & $>500$ & $>300$ & $200-800$ \\
\hline Pollen sacs/sorus & Up to 8 & $2-4$ & $2-5$ & $2-5$ & Usually 2 & ? & $2-5$ & $2-5$ & $2-5$ & $2-5$ & $2-5$ & $2-5$ \\
\hline
\end{tabular}

Sources. Compiled from Chamberlain (1935); Stevenson (1990); Norstog and Nicholls (1997); Jones (2002); Whitelock (2002).

${ }^{a}$ Length and orientation of spine(s) can vary from base to apex of cone; may be curved backward or downward.

${ }^{b}$ Lower edge of central or lower facet may be toothed or scalloped.

" Spine may be reduced at the base of the cone, more elongate toward the apex. 
A curious feature of the microsporophylls is the morphology of the distal face (fig. 4A, 4B). There appear to be at least two morphotypes in fossil cycadalean cones reported to date. Although no fossil cone has yet been identified with peltate microsporophylls, fossil cycad cones can be distinguished on the basis of the presence or absence of projections on the distal face of microsporophylls. Cones assigned to the genus $\mathrm{An}$ drostrobus do not display significant projections on the sporophyll face (Schimper 1870-1872). In contrast, spinelike distal projections have been described in Liulinia lacinulata Wang from the uppermost Permian of China, although the numerous projections on this compression specimen are interpreted as blunt (Wang 1986). Microsporophylls of the cone of Leptocycas gracilis Delevoryas et Hope from the Upper Triassic of North America also have elongate apical projections (Delevoryas and Hope 1971). Reexamination of the type material of L. gracilis reveals that microsporophylls have at least one sharp-tipped projection at the distal face that extends laterally up to $5 \mathrm{~mm}$. Although this feature alone is not a definitive basis for establishing relationships among early cycads, variation in microsporophyll morphology is a character that is taxonomically informative at the generic level in extant taxa (Stevenson 1990; Norstog and Nicholls 1997; Jones 2002; Whitelock 2002). Where present, these projections range from the beaklike extension of a central facet of the face in Encephalartos Lehmann to two well-defined spines in Ceratozamia Brongniart to a single spine, sometimes with minute spines on either side, in many species of Cycas (table 1) (Jones 2002; Whitelock 2002). As more is learned about sporophyll morphology in fossil cycad cones, this feature may become more important in defining taxonomic lineages.

The arrangement of the face of the microsporophylls is another feature that is consistent within taxonomic groups of modern cycads. All extant taxa bear microsporophylls in a helical arrangement, but this can manifest as two different patterns of organization on the basis of the shape of the microsporophyll face. Cones of Cycadaceae and some Zamiaceae (Encephalartae and Diooaeae) display an imbricating spiral of rhomboidal faces, while those in Stangeriaceae and other $\mathrm{Za}$ miaceae (Zamieae and Ceratozamieae) have vertical rows of hexagonal faces (table 1). All fossil cycad cones known to date, including $D$. spinulosa, display an imbricating arrangement of microsporophylls with rhomboidal faces (fig. 4A).

\section{Fossil Record of Cycad Pollen Cones}

Cycads are believed to have originated during the late $\mathrm{Pa}-$ leozoic, possibly during the Carboniferous (Scott 1897; Worsdell 1906; Mamay 1976; Taylor and Taylor 1993), although much of the fossil evidence for this hypothesis is equivocal. Whereas there are numerous Late Carboniferous-Early Permian leaf compressions that have been assigned to the cycads (e.g., Taeniopteris Brongniart, Archaeocycas Mamay, and Phasmatocycas Mamay; Mamay 1973, 1976), there are few reports of cycad reproductive structures. Lasiostrobus polysacci Taylor was originally described as a cycad (Taylor 1968) but later compared with cycads, conifers, and ginkgophytes (Taylor 1970). Today, this fossil's correct taxonomic placement remains an enigma (Taylor and Millay 1977). Hu et al. (1999a) briefly describe ovulate cycad sporophylls from the Upper Car- boniferous in China; however, this occurrence has not yet been documented in greater detail. Other fossils suggested as cycads include impressions and molds of conelike structures from the Lower Permian of Texas and an isolated megasporophyll assigned to Cycadospadix Schimper (Mamay 1976). The most convincing evidence to date of the presence of cycads in the late Paleozoic comes from the Permian of China and includes compression specimens of leaves, ovulate megasporophylls, and pollen cones (Zhu and Du 1981; Wang 1986; Gao and Thomas 1989; Zhu et al. 1994; Hu et al. 1999a, 1999b; Liu and Yao 2002). These fossils provide compelling evidence for strobilar organization in both pollen and seed-bearing reproductive organs in the latest Paleozoic cycads and support the hypothesis that ancestors of cycads may date to the Carboniferous.

The fossil record of cycads in the Mesozoic is more complete but complicated by similarities in vegetative structure of cycads and Bennettitales (cycadeoids). There are numerous reports of fossil cycad leaves and stems (review in Norstog and Nicholls 1997), yet reproductive structures remain poorly known or inaccurately identified. Most fossil cones suggested as belonging to cycads occur in isolation, although a single pollen cone has been found attached to the apex of a stem of $L$. gracilis (Delevoryas and Hope 1971). The cone is ca. $6 \mathrm{~cm}$ long and $1.5 \mathrm{~cm}$ wide, but additional details of its structure are not well preserved. The pollen cones C. profusa from the Jurassic of Georgia and S. laxa from the Cretaceous of Russia (Krassilov and Bugdaeva 1988; Krassilov et al. 1996) provide some evidence of diversity in Mesozoic cycads. Many other putative cycad cones have been assigned to Androstrobus, with at least 16 species described from Upper Triassic-Cretaceous localities in Europe and China (Schimper 1870; Saporta 1875; Heer 1876; Nathorst 1878; Seward 1895; Harris 1941, 1964; Stanislavski 1957; Roselt 1960; Thomas and Harris 1960; van Konijnenburg-van Cittert 1968, 1993; Hill 1990; Hu et al. $1999 b$ ). Although cycadalean pollen has been identified in some of these species (Harris 1941; van Konijnenburg-van Cittert 1968, 1993; Hill 1990), the validity of assignment of others to the Cycadales is questionable, and revision of Androstrobus is sorely needed (Harris 1964). Cones of Androstrobus range up to $7 \mathrm{~cm}$ long and are characterized by imbricating microsporophylls that lack distal projections (Schimper 1870; van Konijnenburg-van Cittert 1968). Hill (1990) suggests that Androstrobus most closely resembles cones of extant Zamiaceae; however, this sheds little light on familial affinities because characters of pollen cones in Zamiaceae sensu Stevenson 1990 encompass nearly all of the variation that occurs in cycads (table 1).

\section{Systematic Considerations}

The cycadophytes (Cycadales and Bennettitales) were significant elements of many Mesozoic ecosystems worldwide but today are represented by only one order that is comprised of 11 genera and ca. 300 species (Jones 2002; Whitelock 2002). Extant Cycadales include three families: Cycadaceae, Zamiaceae, and Stangeriaceae (Stevenson 1990, 1992). Cycadaceae, with the single genus Cycas, has historically been interpreted as the most basal family, and this is supported in recent phylogenetic analyses (Stevenson 1990; Caputo et al. 1991; Nixon 
et al. 1994; Rydin et al. 2002; Treutlein and Wink 2002). Zamiaceae is consistently regarded as the most derived, although relationships among the eight genera included in the family remain unresolved (Crane 1988; Stevenson 1990; Treutlein and Wink 2002). The monophyly of Stangeriaceae (Stangeria + Bowenia) has recently been challenged on the basis of molecular and cytological studies, and it appears that Stangeria may be more closely related to Zamia than to Bowenia (Kokubugata et al. 2002; Treutlein and Wink 2002; Bogler and Francisco-Ortega, in press; Rai et al. 2003). Nearly all phylogenetic analyses of seed plants based on morphology score cycads on the basis of characters of the extant taxa; only a few include any fossil representatives of the order (Doyle and Donoghue 1986, 1992; Doyle 1996). Assessment of possible systematic affinities and phylogenetic relationships of fossil cycads has been limited, in part because of the lack of detailed information on reproductive structures but also because phylogenetic analyses have used characters that either cannot be ascertained (e.g., presence of cycasin) or have not been used in fossil taxa (e.g., trichome characteristics) (Crane 1985, 1988; Stevenson 1990). In addition, these analyses generally use a limited suite of cycad morphological and anatomical features, particularly with respect to pollen cones. With the exception of the work of Stevenson (1980a, 1980b, 1981, $1988,1990)$, this is probably a reflection of nearly a century of neglect in detailed anatomical and developmental studies of extant cycads.

In their description of A. schopfii, Smoot et al. (1985) are cautious in assigning the fossil to a modern cycad family and suggest tentative affinities with Stangeriaceae/Zamiaceae on the basis of the observation that its anatomical organization is similar to that of Bowenia. Some of the features of Delemaya are more similar to pollen cones of Cycas (Cycadaceae) and Macrozamia (Zamiaceae), which have imbricating, planar microsporophylls with one or more distal spines; however, $\mathrm{Za}$ mia, Chigua, and Bowenia are all characterized by a reduced number of pollen sacs per microsporophyll (table 1). Nonetheless, sufficient differences separate $D$. spinulosa from these taxa, including the extremely reduced number of pollen sacs per microsporophyll (ca. 16 vs. $50-1000$ or more), greater number of pollen sacs per radial cluster (up to eight vs. up to five), and synangiate organization of the pollen sacs. On the basis of $r b c \mathrm{~L}$ sequence data, Treutlein and Wink (2002) suggest that the split between Cycadaceae and Zamiaceae occurred in the late Mesozoic, with a relatively recent radiation of most extant species of cycads. If this hypothesis is accurate, it is perhaps not surprising that this early Mesozoic pollen cone appears to possess characters of both Cycadaceae and Zamiaceae as well as features that are unique. We believe that these characters must be interpreted with caution because D. spinulosa is thus far known from an isolated, single specimen, which does not provide information on the full range of variation that no doubt existed. The unique characters of this pollen cone, however, when examined with the anatomical features of the cycad stem A. schopfii, suggest that assignment to a modern cycad family is perhaps premature at this time.

\section{Pollination Biology}

Delemaya spinulosa is a small cone with a reduced number of pollen sacs and therefore lower pollen production when compared with the pollen cones of modern cycads (Norstog and Nicholls 1997). This raises the question about how pollination was achieved in this early cycad. One method to compensate for a relatively low pollen output is for the plant to have produced multiple cones, possibly on multiple stems. This strategy is employed by several modern genera; Zamia can produce more than a dozen cones on a single stem, while multibranched Macrozamia has been documented with up to 100 pollen cones (Chamberlain 1935; Norstog and Nicholls 1997). The small size of stems of A. schopfii $(<4 \mathrm{~cm}$ in diameter), the probable parent plant, would seem to preclude the production of many cones at one time, but it remains possible that it had a branching habit.

On the basis of what we now know about pollination mechanisms in modern cycads, it is possible to envision that this fossil cycad may have attracted insects that acted as a vector for a more sophisticated, directed, biotic pollination syndrome. It has become increasingly clear that most, if not all, modern cycads depend on insect pollinators (Norstog et al. 1986; Tang 1987; Norstog and Fawcett 1989; Vovides 1991; Donaldson 1997; Norstog and Nicholls 1997; Stevenson et al. 1998; Mound and Terry 2001; Terry 2001; Jones 2002). Members of the insect groups that act as pollinators in modern cycads were present in terrestrial environments by the Triassic (Labandeira and Sepkoski 1993), and it has repeatedly been hypothesized that the history of mutual relationships between cycads and insects may date back to the Mesozoic or possibly earlier (Norstog 1987; Norstog and Nicholls 1997; Labandeira 1998; Mound and Terry 2001; Schneider et al. 2002). Indirect evidence for this is provided by isolated cycad pollen sacs containing coprolites that consist exclusively of cycad pollen that occur in association with this cone. This may simply be an instance of opportunistic predation; however, pollinivory has been hypothesized as one of the early steps in establishing such an interaction (Crepet 1979; Labandeira 1998). Research on these intriguing fossils continues.

Renewed interest in the evolutionary history of cycads has been triggered by the discovery of exciting fossils in China as well as recent phylogenetic investigations using molecular data. Nonetheless, interrelationships within the cycadophytes remain poorly understood, as does their phylogenetic position relative to other seed plants. This can be attributed in part to the few reports of fossil cycad reproductive structures. Our understanding of even the living cycads remains in its infancy when measured against the wealth of information that has been gathered for other gymnosperms. The discovery of D. spinulosa from the Middle Triassic of Antarctica presents another perspective on the reproductive biology of fossil cycads. This ultimately may provide a new impetus for incorporating fossil cycad taxa into phylogenetic analyses and contribute to a more complete understanding of the evolutionary history of this extraordinary group of seed plants.

\section{Acknowledgments}

We thank Dennis Stevenson, New York Botanical Garden, for the loan of slides of comparative material of modern cycads; Terrence Walters, Montgomery Botanical Center, Miami, 
for access to the cycad collections; Jeffrey Osborn, Truman State University, Kirksville, Missouri, for assistance with electron microscopy; Bill Chaloner and Gar Rothwell for com- ments that improved the manuscript; and Henri DonerHedrick for the reconstructions. This study was supported in part by National Science Foundation grant OPP 0003620.

\section{Literature Cited}

Audran JC, E Masure 1977 Contribution a la connaissance de la composition des sporoderms chez les Cycadales (Prespermaphytes): etude en microscopie electronique a transmission (M.E.T.) et a balayage (M.E.B.). Palaeontogr Abt B 162:115-158.

Aulenback KR, BA LePage 1998 Taxodium wallissii sp. nov.: first occurrence of Taxodium in the Upper Cretaceous. Int J Plant Sci 159:367-390.

Axsmith BJ, TN Taylor, EL Taylor 1998 Anatomically preserved leaves of the conifer Notophytum krauselii (Podocarpaceae) from the Triassic of Antarctica. Am J Bot 85:704-713.

Barrett PJ, DH Elliott 1973 Reconnaissance geologic map of the Buckley Island Quadrangle, Transantarctic Mountains, Antarctica: Antarctic geological map (U.S. Geological Survey) A-3. U.S. Geological Survey, Washington, D.C.

Bierhorst DW 1971 Morphology of vascular plants. Macmillan, New York. 560 pp.

Bogler D, J Francisco-Ortega In press Molecular systematic studies in cycads: evidence from $t r n \mathrm{~L}$ intron and ITS2 rDNA sequences. Mem N Y Bot Gard.

Caputo P, DW Stevenson, ET Wurtzel 1991 A phylogenetic analysis of American Zamiaceae (Cycadales), using chloroplast DNA restriction fragment length polymorphisms. Brittonia 43:135-145.

Chamberlain CJ 1935 Gymnosperms: structure and evolution. University of Chicago Press, Chicago. 484 pp.

Coulter JM, CJ Chamberlain 1917 Morphology of gymnosperms. University of Chicago Press, Chicago. 466 pp.

Crane PR 1985 Phylogenetic analysis of seed plants and the origin of angiosperms. Ann Mo Bot Gard 72:716-793.

1988 Major clades and relationships in the "higher" gymnosperms. Pages 218-272 in CB Beck, ed. Origin and evolution of gymnosperms. Columbia University Press, New York.

Crepet WL 1979 Insect pollination: a paleontological perspective. BioScience 29:102-108.

Dehgan B, NB Dehgan 1988 Comparative pollen morphology and taxonomic affinities in Cycadales. Am J Bot 75:1501-1516.

Delevoryas T, RC Hope 1971 A new Triassic cycad and its phyletic implications. Postilla 150:1-14.

Donaldson JS 1997 Is there a floral parasite mutualism in cycad pollination? the pollination biology of Encephalartos villosus (Zamiaceae). Am J Bot 84:1398-1406.

Donoghue MJ, JA Doyle 2000 Seed plant phylogeny: demise of the anthophyte hypothesis? Curr Biol 10:R106-R109.

Doyle JA 1996 Seed plant phylogeny and the relationships of Gnetales. Int J Plant Sci 157(suppl):S3-S39.

- 1998 Phylogeny of vascular plants. Annu Rev Ecol Syst 29: 567-599.

Doyle JA, MJ Donoghue 1986 Seed plant phylogeny and the origin of angiosperms: an experimental cladistic approach. Bot Rev 52: $321-431$.

1992 Fossils and seed plant phylogeny reanalyzed. Brittonia 44:89-106.

Farabee MJ, EL Taylor, TN Taylor 1990 Correlation of Permian and Triassic palynomorph assemblages from the central Transantarctic Mountains, Antarctica. Rev Palaeobot Palynol 65:257-265.

Galtier J, TL Phillips 1999 The acetate peel technique. Pages 67-70 in TP Jones, NP Rowe, eds. Fossil plants and spores: modern techniques. Geological Society, London.

Gao Z, BA Thomas 1989 A review of cycad megasporophylls, with new evidence of Crossozamia Pomel and its associated leaves from the Lower Permian of Taiyuan, China. Rev Palaeobot Palynol 60: 205-223.

Gifford EM, AS Foster 1989 Morphology and evolution of vascular plants. 3d ed. WH Freeman, New York. 626 pp.

Grauvogel-Stamm L 1969 Nouveaux types d'organses reproducteurs mâles de conifères du grès a Voltzia (Trias inférieur) des Vosges. Bull Serv Carte Geol Als Lorr 22:93-120.

Hammer WR, JW Collinson, WJ Ryan III 1990 A new Triassic vertebrate fauna from Antarctica and its depositional setting. Antarct Sci 2:63-167.

Harris TM 1941 Cones of extinct Cycadales from the Jurassic rocks of Yorkshire. Philos Trans R Soc Lond B Biol Sci 231:75-98.

1964 The Yorkshire Jurassic flora: Caytoniales, Cycadales and pteridosperms. Vol 2. British Museum (Natural History), London. 191 pp.

Heer O 1876 Beiträge zur Jura-Flora Ostsiberiens und des Amurlandes: flora fossilis arctica. Band 4, heft 2. Acad Imp Sci StPétersbourg Mem 22:1-122.

Hill CJ 1990 Ultrastructure of in situ fossil cycad pollen from the English Jurassic, with a description of the male cone Androstrobus balmei sp. nov. Rev Palaeobot Palynol 65:165-174.

$\mathrm{Hu}$ YF, ZD Chen, CJ Chen, BY Geng 1999a Discoveries of some fossils of cycad reproductive organs from China and their significance to the origin of cycads. Pages 135-141 in CJ Chen, ed. Biology and conservation of cycads: proceedings of the fourth international conference on cycad biology. International Academic, Beijing.

Hu YF, YS Lu, J Ma 1999 birst discovery of Androstrobus Schimper in Panzhihua, China and its paleobiological and geographical significance. Pages 129-134 in CJ Chen, ed. Biology and conservation of cycads: proceedings of the fourth international conference on cycad biology. International Academic, Beijing.

Jones DL 2002 Cycads of the world: ancient plants in today's landscape. $2 \mathrm{~d}$ ed. Smithsonian Institution, Washington, D.C. 456 pp.

Kokubugata G, KD Hill, K Katsuhiko 2002 Ribosomal DNA distribution in somatic chromosomes of Stangeria eriopus (Stangeriaceae, Cycadales) and molecular-cytotaxonomic relationships to some other cycad genera. Brittonia 54:1-5.

Krassilov VA, EV Bugdaeva 1988 Protocycadopsid pteridosperms from the Lower Cretaceous of Transbaikalie and the origin of cycads. Palaeontogr Abt B 208:27-32.

Krassilov VA, GV Delle, HV Vladimirova 1996 A new Jurassic pollen cone from Georgia and its bearing on cycad phylogeny. Palaeontogr Abt B 238:71-75.

Labandeira CC 1998 How old is the flower and the fly? Science 280: 57-59.

Labandeira CC, JJ Sepkoski Jr 1993 Insect diversity in the fossil record. Science 261:310-315.

Liu L, Z Yao 2002 Lepingia: a new genus of probable cycadalean affinity with taeniopterid lamina from the Permian of south China. Int J Plant Sci 163:175-183.

Magallón S, MJ Sanderson 2002 Relationships among seed plants inferred from highly conserved genes: sorting conflicting phylogenetic signals among ancient lineages. Am J Bot 89:1991-2006.

Mamay SH 1973 Archaeocycas and Phasmatocycas: new genera of Permian cycads. U S Geol Surv J Res 1:687-689.

1976 Paleozoic origins of the cycads. U S Geol Surv Prof Pap 934:1-48.

Marshall J, N Grobbelaar, J Coetzee, R Osborne 1989 Pollen mor- 
phology of the Cycadales with special reference to the Encephalartos species. Pollen Spores 31:229-249.

Meyer-Berthaud B, TN Taylor 1991 A probable conifer with podocarpacean affinities from the Triassic of Antarctica. Rev Palaeobot Palynol 67:179-198.

Millay MA, TN Taylor 1977 Feraxotheca gen. n., a lyginopterid pollen organ from the Pennsylvanian of North America. Am J Bot 64: 177-185.

1979 Paleozoic seed fern pollen organs. Bot Rev 45:301-375.

Mound LA, I Terry 2001 Thrips pollination of the central Australia cycad, Macrozamia macdonnellii (Cycadales). Int J Plant Sci 162: 147-154.

Nathorst AG 1878 Bidrag till Sveriges, fossila flora. 2. Floran, vid Hogans och Helsinborg. K Sven Vetenskapsakad Handl 16:1-53.

Nixon KC, WL Crepet, D Stevenson, EM Friis 1994 A reevaluation of seed plant phylogeny. Ann Mo Bot Gard 81:484-533.

Norstog K 1987 Cycads and the origin of insect pollination. Am Sci 75:270-279.

Norstog K, PKS Fawcett 1989 Insect-cycad symbiosis and its relation to the pollination of Zamia furfuracea (Zamiaceae) by Rhopalotria mollis (Circulionidae). Am J Bot 76:1380-1394.

Norstog K, DW Stevenson, KJ Niklas 1986 The role of beetles in the pollination of Zamia furfuracea L. fil. (Zamiaceae). Biotropica 18: 300-306.

Norstog KJ, TJ Nicholls 1997 The biology of the cycads. Cornell University Press, Ithaca, N.Y. 363 pp.

Osborn JM, TN Taylor 1993 Pollen morphology and ultrastructure of the Corystospermales: permineralized in situ grains from the Triassic of Antarctica. Rev Palaeobot Palynol 79:205-219.

Qiu YL, J Lee, F Bernasconi-Quadroni, DE Soltis, PS Soltis, M Zanis, EA Zimmer, et al 2000 Phylogenetic analyses of basal angiosperms based on five genes from all three genomes. Int J Plant Sci 161(suppl): S3-S27.

Rai HS, HE O’Brien, PA Reeves, RG Olmstead, SW Graham 2003 Inference of higher-order relationships in the cycads from a large chloroplast data set. Mol Phylogenet Evol 29:350-359.

Roselt G 1960 Neue Cycadophyten-reste aus dem unteren Keuper. Senckenb Lethaea 41:121-137.

Rothwell GW 1980 The Callistophytaceae (Pteridospermopsida). II. Reproductive features. Palaeontogr Abt B 173:85-106.

Rothwell GW, R Serbet 1994 Lignophyte phylogeny and the evolution of spermatophytes: a numerical cladistic analysis. Syst Bot 19: 443-482.

Rydin C, Källersjö M, Friis EM 2002 Seed plant relationships and the systematic position of Gnetales based on nuclear and chloroplast DNA: conflicting data, rooting problems, and the monophyly of conifers. Int J Plant Sci 163:197-214.

Sanderson MJ, JA Doyle 2001 Sources of error and confidence intervals in estimating the age of angiosperms from $r b c L$ and $18 \mathrm{~S}$ rDNA data. Am J Bot 88:1499-1516.

Saporta G 1875 Paléontologie Française ou description des fossiles de la France. 2e série-Végétaux, Plantes Jurassiques. Tome II. Cycadées. G Masson, Paris. 352 pp.

Schimper WP 1870-1872 Traité de paléontologie végétale ou la flore du monde primitif dans ses rapports avec les formations géologiques et la flore du monde actuel. Vol 2. Baillière, Paris. 968 pp.

Schneider D, M Wink, F Sporer, P Lounibos 2002 Cycads: their evolution, toxins, herbivores and insect pollinators. Naturwissenschaften 89:281-294.

Scott DH 1897 The anatomical characters presented by the peduncle of Cycadaceae. Ann Bot 11:399-419.

1909 Studies in fossil botany. 2d ed. Vol 2. Adam \& Charles Black, London.

Seward AC 1895 Catalogue of the Mesozoic plants in the Department of Geology, British Museum: the Wealden Flora. Pt 2. Gymnospermae. British Museum (Natural History), London. 259 pp.
Smoot EL, TN Taylor, T Delevoryas 1985 Structurally preserved fossil plants from Antarctica. I. Antarcticycas, gen. nov., a Triassic cycad stem from the Beardmore Glacier area. Am J Bot 72:14101423.

Soltis DE, PS Soltis, MJ Zanis 2002 Phylogeny of seed plants based on evidence from eight genes. Am J Bot 89:1670-1681.

Stanislavski FA 1957 Jurassic plants from the Don Basin and DnieperDonetz region. Akademii Nauk Ukraine SSR, Kiev. 128 pp. (In Russian.)

Stevenson DW 1980 a Observations on stem and root contraction in cycads (Cycadales) with special reference to Zamia pumila L. J Linn Soc Bot 81:275-281.

1980b Radial growth in the Cycadales. Am J Bot 67:673678.

1981 Observations on the ptyxis, phenology, and trichomes in the Cycadales and their systematic implications. Am J Bot 68: 1104-1114.

1988 Strobilar ontogeny in the Cycadales. Pages 205-244 in P Leins, S Tucker, P Endress, eds. Aspects of floral development. Cramer, Berlin.

1990 Morphology and systematics of the Cycadales. Mem N Y Bot Gard 57:8-55.

- 1992 A formal classification of the extant cycads. Brittonia 44:220-223.

Stevenson DW, KJ Norstog, PKS Fawcett 1998 Pollination biology of cycads. Pages 277-294 in SJ Owens, PJ Rudall, eds. Reproductive biology. Royal Botanic Gardens, Kew.

Stidd BM, JW Hall 1970 Callandrium callistophytoides, gen. et sp. nov., the probable pollen-bearing organ of the seed fern, Callistophtyon. Am J Bot 57:394-403.

Tang W 1987 Insect pollination in the cycad Zamia pumila (Zamiaceae). Am J Bot 74:90-99.

Taylor EL, TN Taylor, NR Cúneo 2000 Permian and Triassic high latitude paleoclimates: evidence from fossil biotas. Pages 321-350 in BT Huber, KC Macleod, SL Wing, eds. Warm climates in earth history. Cambridge University Press, New York.

Taylor TN 1968 Cycads: evidence from the Upper Pennsylvanian. Science 164:294-295.

_ 1970 Lasiostrobus gen. n., a staminate strobilus of gymnospermous affinity from the Pennsylvanian of North America. Am J Bot 57:670-690.

Taylor TN, MA Millay 1977 The ultrastructure and reproductive significance of Lasiostrobus microspores. Rev Palaeobot Palynol 23: 129-137.

Taylor TN, EL Taylor 1993 The biology and evolution of fossil plants. Prentice Hall, Englewood Cliffs, N.J. 982 pp.

Terry I 2001 Thrips and weevils as dual, specialist pollinators of the Australian cycad Macrozamia communis (Zamiaceae). Int J Plant Sci 162:1293-1305.

Thibout E 1896 Recherches sur l'appareil mâle des gymnosperms. $\mathrm{PhD}$ diss. Université de Lille.

Thomas HH, TM Harris 1960 Cycadean cones of the Yorkshire Jurassic. Senckenb Lethaea 41:139-161.

Thorne JL, H Kishino 2002 Divergence time and evolutionary rate estimation with multilocus data. Syst Biol 51:689-702.

Treutlein J, M Wink 2002 Molecular phylogeny of cycads inferred from $r b c L$ sequences. Naturwissenschaften 89:221-225.

Van Konijnenburg-van Cittert JHA 1968 Androstrobus major, a new male cycad cone from the Jurassic of Yorkshire (England). Rev Palaeobot Palynol 7:267-273.

1993 Androstrobus phialophora (Harris) nov. comb., a new name for Bernettia phialophora from the Liassic of Greenland. Rev Palaeobot Palynol 77:301-304.

Vovides AP 1991 Insect pollination in some Mexican cycads in their natural habitat. Biotropica 23:102-104.

Wang Z 1986 Liulinia lacinulata: a new male cone of cycads from 
the latest Permian in Shanxi. Acta Palaeontol Sin 25:610-616. (In Chinese with English summary.)

Whitelock LM 2002 The cycads. Timber, Portland, Oreg. 374 p.

Worsdell WC 1896 The anatomy of the stem of Macrozamia compared with that of other genera of Cycadaceae. Ann Bot 19:601620.

1898 The vascular structure of the sporophylls of Cycadaceae. Ann Bot 12:203-241.

1906 The structure and origin of the Cycadaceae. Ann Bot 20:129-159.
Yao X, TN Taylor, EL Taylor 1997 A taxodiaceous seed cone from the Triassic of Antarctica. Am J Bot 84:343-354.

Zhu J, X Du 1981 A new cycad: Primocycas chinensis gen. et sp. nov. discovered from the Lower Permian in Shanxi, China and its significance. Acta Bot Sin 23:401-404. (In Chinese with English abstract.)

Zhu JN, XS Zhang, M Jie 1994 A new genus and species: Cycadostrobilus paleozoicus Zhu of Cycadaceae from the Permian of China. Acta Phytotaxon Sin 32:340-344. (In Chinese with English abstract.) 
Copyright of International Journal of Plant Sciences is the property of University of Chicago Press and its content may not be copied or emailed to multiple sites or posted to a listserv without the copyright holder's express written permission. However, users may print, download, or email articles for individual use. 